\title{
Evaluating Food and Beverage Courses in Higher Private Tourism and Hotels Institutes in Alexandria: Professionals' Perception Youssef Agwa ${ }^{1}$ Waeal Aziz ${ }^{2}$ Gamal Khalifa ${ }^{3}$ ${ }^{1} \mathrm{PhD}$ Researcher, Faculty of Tourism and Hotels, Fayoum University \\ ${ }^{2}$ Faculty of Tourism and Hotels, Mansoura University \\ ${ }^{3}$ Faculty of Tourism and Hotels, Fayoum University
}

\begin{abstract}
The evaluation of Food and beverage courses is an important in the hospitality education since almost every hospitality program offers at least one course in food and beverage management that provides a kitchen and dining room type environment. Thus this study aimed to assess the perception of professionals' on the food and beverage courses relating issues in higher private tourism and hotels institutes in Alexandria, Egypt. A purposive sample of $50 \mathrm{~F} \& \mathrm{~B}$ professionals (25 from Kitchen and 25 from food service) were interviewed using structured interview. Data obtained were analyzed qualitatively using thematic approach. The findings exposed that there is a variation among the professionals with regard to their level of professionalism and academic qualifications. While some of them have the required skills and professionalism which are enough and meet the requirements, other believed that there is more need for teaching staff to be trained and developed.
\end{abstract}

Keywords: Food and beverage, Egypt, Higher education, tourism and Hotels, professionals.

\section{Introduction}

Food and beverage $(\mathrm{F} \& \mathrm{~B})$ courses have been an essential part of hospitality management curricula (Baker et al. 1995; Ford and LeBrunto, 1995). However, Baker et al. (1995) reported that there is a wide range of discrepancies in the opinions of the stakeholders' collection and the appropriateness of food and beverage sessions in the college has been heavily criticized. It was also indicated that development of practical skills has been traditionally a clear focus to food and beverage teaching and constitutes hospitality requisite to graduates. The focus of hospitality programmes (Ford and Lebrunto, 1995) is being centered to develop technical operational skills with particular emphasis upon food and beverage.

Teaching food and beverage has been reported to be at the core of hospitality management programmes (Gillespie and Baum, 2000).Courses important for career success include food and beverage management, menu planning and preparation, beverage, restaurant management, and convention and banquet management were classified as the most important courses for career success.

Fundamentally, food production or culinary art is the only manufacturing function in hospitality (Jones, 2004); it is the most complex operation with multiple inputs, which are technological and operational in nature. Food service technologies are grounded in the principles of chemistry, biology, microbiology, engineering and mathematics, the disciplines with well-established theory and high degree of academic vigor. Millar et al. (2010) reported that blend of hospitality and food based combination is relatively young field and experienced limited developments but remarkably growing subject and departments.

Earlier, Cousins, et al. (2002) reported that food production and service operation is an integral process of hospitality industry and cannot be separated from management. They affirmed that processing of materials and services are essential elements of teaching food and beverage operation. This means that Food and beverage management features as a significant part of the curriculum in most hospitality management programmes. It is 
invariably seen as a practical subject broadly focused on two distinct sub-areas, food production and food service. Indeed, insofar as hospitality is a distinctive form of management and managerial activity, food and beverage management together with the management of accommodation defines this distinctiveness (Wood, 1997).

There are several factors that influence producing quality balanced hotel studies curriculum and the manners by which the universities in Egypt tailor and deliver this field of study. To the knowledge of the author of the current study, no academic research has been produced to investigate the evaluation of $\mathrm{F} \& \mathrm{~B}$ courses including their numbers and quality as viewed by different stakeholders, including, the professionals of the hospitality industry in Egypt.

Thus, and based on the previous introduction, this study aims to assess the perception of professionals' on the food and beverage courses relating issues in higher private tourism and hotels institutes in Alexandria, Egypt.

\section{Literature review}

Tourism has been the subject of research and scholarly treatments for several decades. Early studies featured mostly economic prospects of tourism, emphasizing its benefits. Gradually, this independent economic view gave way to a wave of studies focusing on the socio-cultural aspects of tourism and brought the benefits of tourism under scrutiny. Thirdly, research then focused on alternative forms of tourism development which were potentially sustainable, with minimal unwanted consequences. All of these research orientations led to systematic research towards the formation of a body of knowledge on tourism. It is suggested that tourism research and scholarship will continue at a more rapid pace in the future (Jafari et al., 1990).

The study and provision of tourism and hospitality education in Egypt is relatively new. However, over the past 50 years, Egypt has expanded considerably its university and higher educational provision for tourism and hotel studies and the number of hospitality technical schools has increased considerably (Hewedi et al., 1998; Kattara et al., 2004). Egypt needs such a system of vocational higher education. Although, hospitality education is of particular importance to the Egyptian economy, it is currently a focus of widespread debate. The major stakeholders include educationalists, employers, policy makers, and leading practitioners.

The ultimate goal of hospitality education should be to put in place the facilities, events and programmes that will be required to produce highly qualified and trained personnel to meet customer or exceed customer expectation and to provide value for money (value = quality in relation to price). Developing the professionalism of the graduates is also a clear objective of hospitality education. Meanwhile, lack of cooperation between the hospitality industry organizations and educational bodies in Egypt is very obvious and has consequently resulted in weaker links between the theoretical approach and practical application (Hewedi et al., 1998).

For decades, the Egyptian tourism higher education has been a crucial concern for all sectors of the society. This discipline has gained interest of several researches in different specific issues including quality, competences and skills (Botterill, 2002; Horng et al. 2009). Curriculum development and the link between industry and academics, employers attitude, students perception (Hjalager, 2003; Roney and Oztin, 2007), and e-learning in tourism education was also investigated (Afifi, 2011).

Regardless the type or the nature of higher tourism and hotel education establishments, the Egyptian tourism and hospitality sector of higher education includes three major specialties namely: Tourism Studies, Hotel Studies and Tourism guidance. In 2010, Egyptian Tourism and hospitality sector of higher education represents $4.9 \%$ of the total force of higher education in terms of numbers of students enrolled. Recently, this sector 
has an average student academic staff ratio of 114:1 (Abdel Hamid, 2010). However, there is alarming fact and concern towards the mismatch between the number of the graduates and the market needs and more importantly the quality of the graduates.

Furthermore, hospitality education requires: staff, students, buildings, library, resources and laboratories, or kitchens, restaurants and other specialist accommodation facilities. Problems encountered by universities include a lack of sufficient finance, shortage of trained staff and the heterogeneity of the student population (Abdel Hamid, 2010). Inevitably different students show varying abilities to adapt to the subject matter and academic content.

Historically, extensive career experience in food and beverage management within the hotel sector has been seen as a necessary prerequisite to progress for becoming a general manager, more than an experience in the room's division (O'Mahony et al., 2001). Although it is unclear as to whether this is still the case, within hospitality management education it has not much altered the strong central concept of a practically oriented food production and service model of food and beverage (Breiter \& Dements, 1996; Scheule \& Sneed, 2001).

Additionally, tourism is strongly linked with food and beverage from different perspectives including production, preparation and safety. It is one of the essential elements of the tourist experience and has gained great attention of researchers and become a subject of study in its own right. Several reasons can be put forward for the growth in attention to food as an area of interest for tourism studies (Hall et al., 2004).

Teaching food and beverage has been reported to be at the core of hospitality management programmes (Baker et al., 1995; Gillespie and Baum, 2000; Lin, 2002). They added that this tradition is maintained in some departments although it has been going on in Europe since 19th century. Courses important for career success as reported by Chung (2000) include food and beverage management, menu planning and preparation, beverage, restaurant management, and convention and banquet management were classified as the most important courses for career success.

Gillespie and Baum (2000) reported that blend of hospitality and food based combination is relatively young field and experienced limited developments but remarkably growing subject and departments. Cousins et al. (2002) as well as reported that food production operation is an integral process of hospitality industry and cannot be separated from management. They affirmed that processing of materials and services are essential elements of teaching food and beverage operation. Hospitality management and home economics programmes are food science, nutrition and production dominated (Goodman and Sprague, 1991; Harrington et al., 2005).

Qualifications standards of hospitality/hotel educators/instructors have been an issue of discrepancy and there are different opinions. While Hill (1995) is in favor of hiring industry-experienced and non-doctorate hospitality educators, Phelan et al. (2013) and Wu et al. (2014) pointed out that both industry-based instructors and academically trained staff is essential to initiate students into a combination of knowledge and real work experience. According to Phelan et al. (2013) a mixed faculty of Ph.D holders and those with industry experience are appropriate to deliver hospitality education.

Overall, the educators need to be abreast of the new industry trends and convey them to the classrooms (Stutts, 1995). Industry has offered the programs forms of support including field trips, classrooms, presentation and internship. Educators are challenged to ensure that future foodservice professionals are prepared to be leaders in the prevention of food borne illness. Many countries have suffered from an acute shortage of specialized food and beverage production skilled staff (Goldsmith and Zahari, 1994). Unklesbay et al (1998) recommended food-based information for students in all college disciplines. Finally, 
according to Fields (2002) and Walczak (1997) found that involvement of restaurant managers in teaching hospitality is essential. Management must provide F\&B related training, enough time, necessary equipment, and high standards of sanitation for employees.

\section{Methodology}

The purpose of this study is to assess the professionals' perception on how high private tourism and hotels institutes in Alexandria are assess and evaluate the food and beverage related courses based on the main elements of the educational process. To that end, this study is a qualitative in its design and nature.

Thus, structured interview schedule was used to assess the professionals' perspective with regarding the evaluation of the different aspects of two F\&B courses: food culinary art and food service. In total, 50 interview forms were distributed and re-collected through the network of the researcher and his colleagues in Alexandria, among executive chefs, Kitchen managers, department managers, restaurant managers, practical instructors of F\&B- related courses, and waiters. The respondents were coded based on the relation to the F\&B courses. For instance, the respondent related to foodservice course was coded as FS1 and the second was FS2 and so on. Similarly, Culinary art respondents were coded $\mathrm{CA}$ and identified by the number of the interview, e.g. CA1, CA2, etc. The respondents were recruited by employing a purposive alongside convenient sample.

The data collection stage started in May 2016 and finished in July 2016. It important to be mentioned, that interview was structured in type. Thus the interview forms were distributed then recollected after about a month. After collecting the data, the coding and analysis using the thematic analysis and procedures were undertaken.

\section{Results and discussion}

\section{Demographic characteristics of the respondents}

Table 1 summarizes the main demographic characteristics of all interviewees participated in the study by filling in the structured interview form for both culinary art and food service courses.

Table1: The demographic characteristics of the respondents

\begin{tabular}{|c|c|c|}
\hline \multirow{2}{*}{ Item } & \multicolumn{2}{|l|}{ Comparison } \\
\hline & Culinary Art & Food service \\
\hline $\begin{array}{l}\text { 1. Name and } \\
\text { contact details }\end{array}$ & $\begin{array}{l}\text { The majority of respondents (17/22) } \\
\text { who filled in the structured } \\
\text { interview on culinary art course } \\
\text { were happy to declare their full } \\
\text { names and contact details. However, } \\
\text { these data are kept confidential and } \\
\text { all the data were coded by CA1 for } \\
\text { first interviewee and so on. }\end{array}$ & $\begin{array}{l}\text { Most of respondents }(18 / 22) \text { who } \\
\text { filled in the structured interview on } \\
\text { food service course were happy to } \\
\text { declare their full names. However, } \\
\text { these names are kept confidential } \\
\text { and all the data were coded by FS1 } \\
\text { for first interviewee and so on. }\end{array}$ \\
\hline 2. Job & $\begin{array}{l}\text { Most of respondents }(19 / 22 ; 86.4 \%) \\
\text { filled out their jobs, and they were } \\
\text { working different job ranging from } \\
\text { practical, supervisory and } \\
\text { managerial jobs: a practical teacher, } \\
\text { a waiter, } 2 \text { academics, } 2 \text { kitchen } \\
\text { managers, } 3 \text { chef de parte, a training } \\
\text { manager, } 3 \text { assistant chef, } 2 \\
\text { executive chef, The vice dean of } \\
\text { EGOTH institute in Alexandria, }\end{array}$ & $\begin{array}{l}\text { The respondents were working } \\
\text { different job ranging from } \\
\text { practical, supervisory and } \\
\text { managerial jobs, : a practical } \\
\text { teacher and hotel expert, } 3 \text { waiters, } \\
3 \text { captains, a } 2 \text { FB managers, } 3 \\
\text { restaurant managers, human } \\
\text { resource manager, an assistant } \\
\text { lecturer, an assistant events } \\
\text { manager, a head waiter, a Maître }\end{array}$ \\
\hline
\end{tabular}




\begin{tabular}{|c|c|c|}
\hline & $\begin{array}{l}2 \text { assistant } F \& B \text { managers, } 2 \text { chefs } \\
\text { de cuisine, a pasta chefs, a hot } \\
\text { kitchen chef, }\end{array}$ & $\begin{array}{l}\text { d'hôtel, chef de parte, First } \\
\text { Counselor of the Egyptian } \\
\text { Company for Tourism and Hotels, } \\
\text { The Director of the educational } \\
\text { restaurants, The Director of the } \\
\text { kitchens hotels institutes EGOTH } \\
\text { Company for tourism, Assistant } \\
\text { F\&B manager. }\end{array}$ \\
\hline $\begin{array}{l}\text { 3. Years of } \\
\text { experiences }\end{array}$ & $\begin{array}{l}\text { The respondents have varied years } \\
\text { of experiences in the field of } \\
\text { culinary art and food service and } \\
\text { hospitality; since most of } \\
\text { respondents }(12 / 22) \text { have experience } \\
\text { ranged } 16-40 \text { years; and } 7 / 22 \text { of } \\
\text { them have work experience ranged } \\
\text { from } 4-15 \text { years, years in this field. }\end{array}$ & $\begin{array}{l}\text { The respondents whom filled in the } \\
\text { structured interview on food } \\
\text { service courses have a varied years } \\
\text { of experiences in the field; since } \\
7 / 22 \text { have worked for more than } 20 \\
\text { years, and } 5 / 22 \text { have experience } \\
\text { ranged } 30-40 \text { years, and the rest of } \\
\text { respondents work from } 10 \text { years in } \\
\text { this field. }\end{array}$ \\
\hline $\begin{array}{l}\text { 4. Current } \\
\text { job }\end{array}$ & $\begin{array}{l}\text { Most of respondents }(11 / 22) \text { worked } \\
\text { for hotels; }(8 / 22) \text { worked for } \\
\text { restaurants in Alex. However, } 3 \text { of } \\
\text { them worked as professional and } \\
\text { practical teachers in institutes } \\
\text { EGOTH Company for tourism. }\end{array}$ & $\begin{array}{l}\text { Most of respondents }(18 / 22) \\
\text { worked for hotels and restaurants } \\
\text { in Alex. However, } 3 \text { of them } \\
\text { worked as professional and } \\
\text { practical teachers in institutes } \\
\text { EGOTH Company for tourism. }\end{array}$ \\
\hline
\end{tabular}

\section{The perception on enrolled students}

Table 2 shows the main evidences and perspectives on the selection of students and how this can influence their food and beverage competences. The opinion of the students' interviews with comparisons between both culinary art and food service courses.

The analysis of interview data showed that most of respondents believed that most of students enrolled in hotels and tourism institutes are not ready or do not have the ability to work in food and beverage department, in particular in food service rather than the kitchen.

Table 2: The perspectives on the enrolled students

\begin{tabular}{|c|l|l|}
\hline \multirow{2}{*}{ Attribute } & Examples of Evidence and Comparisons \\
\cline { 2 - 3 } & Culinary Art & Food service \\
\hline \multirow{2}{*}{} & $\begin{array}{l}\text { Yes, I can argue that the desire of } \\
\text { the students to be enrolled in the } \\
\text { field of tourism and hotels is the } \\
\text { main issue of their willingness and } \\
\text { their desire, skill to work in the } \\
\text { accepted in the hotels do not have the } \\
\text { desire to study in this specialization, and } \\
\text { this affects their interest and desire to } \\
\text { study and abilities upon graduation } \\
\text { (FS1). }\end{array}$ \\
\cline { 2 - 3 } & $\begin{array}{l}\text { Yes, some of the students have the } \\
\text { desire to study, work, and they may } \\
\text { have basic skills, which are the } \\
\text { main pillars in the hotel institutes } \\
\text { to develop well-skilled graduates } \\
\text { (CA2). }\end{array}$ & $\begin{array}{l}\text { Yes, the desire and readiness of students } \\
\text { to join and to work in the service of the } \\
\text { food and beverages play in important } \\
\text { role in the development of their } \\
\text { competences (FS2). }\end{array}$ \\
\cline { 2 - 2 } & $\begin{array}{l}\text { A few of them deserves to be part } \\
\text { of the team of nay kitchen as many } \\
\text { of them do not realize the } \\
\text { significance of the field, which is }\end{array}$ & $\begin{array}{l}\text { Not always, it reflects their readiness } \\
\text { and willingness to work in the service of } \\
\text { the food and drinks there should be } \\
\text { tests, measurement, acceptance }\end{array}$ \\
\hline
\end{tabular}




\begin{tabular}{|l|l|l|}
\hline $\begin{array}{l}\text { studying and their first aim is to } \\
\text { get a certificate and graduation } \\
\text { (CA3). }\end{array}$ & $\begin{array}{l}\text { guidelines and requirements within } \\
\text { institutes for students to work in the } \\
\text { service of the food and drinks (FS3). }\end{array}$ \\
\hline $\begin{array}{l}\text { Yes, they have the desire and } \\
\text { interest and some basics skills to } \\
\text { acquire many culinary related } \\
\text { competencies and skills. However, } \\
\text { not all students like or interest to } \\
\text { oork in this field of hospitality } \\
\text { in the hotel studies and their abilities } \\
\text { and willingness to work in the area of } \\
\text { food services and drinks (FS4). }\end{array}$ \\
$\begin{array}{l}\text { From my experiences in the fields } \\
\text { of tourism education, teaching, } \\
\text { hotel business training in many } \\
\text { educational facilities, I would say } \\
\text { that the level of graduates from the } \\
\text { department of hotels of different } \\
\text { educational institutions is lower } \\
\text { than the required level with regard } \\
\text { to the culinary and cooking skills in } \\
\text { the hotel business (CA8). }\end{array}$ & $\begin{array}{l}\text { Must be the work of electing and } \\
\text { integrating before accepting the students }\end{array}$ \\
\hline
\end{tabular}

For example, one kitchen manager explained that:

I can say that $20 \%$ of the students enrolled in the department of the hotels in the institutes are ready to work in the hotel, which is reflected in the performance of an imbalance Study Years as well as to sharpen their skills, and on the other side, we find that $80 \%$ of them do not have any readiness or willing,(FS11).

Another interviewee argued that:

The majority of the students who are enrolled in the tourism and hotel institutes only because of coordination. Thus most of them have lack of/ no desire in the tourism and hotel education and therefore it affects the level of graduates, as we may find that only $40 \%$ of them are interested in the hotel business and the minority of them have skills to work in the hotel kitchens and a private area of gastronomy (CA8).

\section{The perspective on teaching staff}

The analysis of the interview data showed that most of respondents believed that there is a variation among the interviewees with regard to the level and qualification of the teaching staff. While some of them believed that the current skills and professionalism of the teaching staff are enough and meet the requirements, others though the opposite as compared in table 3. 
Table 3: The comparison of interviewees' perspectives on academic staff

\begin{tabular}{|c|c|c|}
\hline \multirow{2}{*}{ Attribute } & \multicolumn{2}{|c|}{ Examples of evidence and comparison } \\
\hline & Culinary Art & Food service \\
\hline \multirow{3}{*}{ 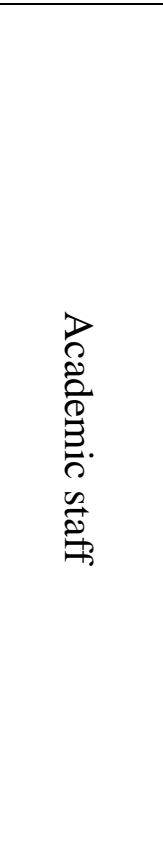 } & $\begin{array}{l}\text { Whenever the academic staff has an } \\
\text { extensive experience of F\&B } \\
\text { teaching, the more the student and } \\
\text { graduates will acquire great and } \\
\text { specific experience and skills in } \\
\text { culinary art (CA1). }\end{array}$ & $\begin{array}{l}\text { In general, staff should have } \\
\text { sufficient expertise or worked in the } \\
\text { field of tourism and hospitality, and } \\
\text { especially those members with } \\
\text { practical or applied (FS2). }\end{array}$ \\
\hline & $\begin{array}{l}\text { They must be experienced in the } \\
\text { practical or applied aspects of the } \\
\text { culinary art beside their scientific } \\
\text { knowledge in the area, so this cans } \\
\text { stimuli the students to like and be } \\
\text { interested in the profession of food } \\
\text { production and culinary art (CA2). }\end{array}$ & $\begin{array}{l}\text { Must have sufficient expertise in the } \\
\text { area of tourism, hotels, both from the } \\
\text { experience of the theory or the } \\
\text { process in order to convey them to } \\
\text { the students (FS3). }\end{array}$ \\
\hline & $\begin{array}{l}\text { I think they are doing their best in } \\
\text { order to facilitate the material and the } \\
\text { related information and knowledge } \\
\text { in the area of culinary art (CA3). }\end{array}$ & $\begin{array}{l}\text { Must have experience in the practical } \\
\text { field of tourism and hotels and be } \\
\text { worked in advance to increase their } \\
\text { expertise in teaching and education of } \\
\text { students (FS5). }\end{array}$ \\
\hline
\end{tabular}

\section{The perspective on contents of $F \& B$ courses}

Additionally, the analysis of the interview data showed that most of respondents believed that there is a variation among the interviewees with regard to the levels of professionalism and up to date contents. While some of them believed that the current contents of food service related courses meet the requirements and enough to build skill and competences required by the market, others though the opposite as compared in table 4 .

Table 4: The perspectives on content of FB courses

\begin{tabular}{|c|c|c|}
\hline \multirow{2}{*}{ Attribute } & \multicolumn{2}{|c|}{ Examples of Evidence and Comparisons } \\
\hline & Culinary Art & Food service \\
\hline \multirow[t]{2}{*}{ 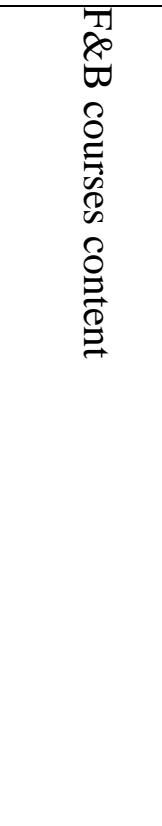 } & $\begin{array}{l}\text { The theoretical contents of culinary } \\
\text { art course are enough privileged } \\
\text { despite the absence of some parts, } \\
\text { however, the practical side is not } \\
\text { updated and not in line with the } \\
\text { current developments in the } \\
\text { culinary in hospitality (CA2). }\end{array}$ & $\begin{array}{l}\text { Unfortunately, there is no an in- } \\
\text { depth specialized text book in food } \\
\text { service and restaurant service. This } \\
\text { means that students do not receive } \\
\text { an extensive knowledge and } \\
\text { information on this area. This also } \\
\text { may because the scarcity of } \\
\text { specialized books (FS1). }\end{array}$ \\
\hline & $\begin{array}{l}\text { There are many gaps between the } \\
\text { practical contents and the } \\
\text { theoretical contents of the culinary } \\
\text { art course (CA4). }\end{array}$ & $\begin{array}{l}\text { The scientific contents of food } \\
\text { service course are excellent, but } \\
\text { more attention and support are } \\
\text { needed to the practical aspect for } \\
\text { improving and increasing the } \\
\text { students' skills through continuous } \\
\text { and direct training for each student } \\
\text { based on the study of this area } \\
\text { (FS7). }\end{array}$ \\
\hline
\end{tabular}




\begin{tabular}{|l|l|l|}
\hline $\begin{array}{l}\text { I think that the scientific contents } \\
\text { of this course require more } \\
\text { development and updating to } \\
\text { contain all the information, skills } \\
\text { and knowledge required for the } \\
\text { graduation of qualified graduates } \\
\text { for the job market (CA10). }\end{array}$ & $\begin{array}{l}\text { The current scientific contents of } \\
\text { foodservice course focus by 70\% on } \\
\text { the theoretical side, and thus more } \\
\text { attention should be paid to the } \\
\text { applied side this will have a positive } \\
\text { impact on the graduates' skills } \\
\text { (FS13). }\end{array}$ \\
\hline $\begin{array}{l}\text { The scientific contents of the } \\
\text { course should contain, whether } \\
\text { theoretical or practical parts on } \\
\text { these topics: Kitchens of the Far } \\
\text { East and Asian, Italian cuisine, and } \\
\text { Mexican cuisine (CA16). }\end{array}$ & $\begin{array}{l}\text { The content of food service course is } \\
\text { acceptable, however, it needs to be } \\
\text { improved and updated to meet the } \\
\text { development in the food and } \\
\text { beverage field which is } \\
\text { contentiously change (FS21). }\end{array}$ \\
\hline
\end{tabular}

\section{The perspective on buildings and facilities}

In the case of the facilities and buildings required for the effective teaching and evaluation of $F \& B$ related courses, the interview results exposed that while most of respondents believed that the current available facilities, including the educational kitchens and restaurants of food service related courses meet the requirements and enough to support the educational process and building the capabilities and skills for graduates, others though the opposite as compared in table 5.

Table 5 the comparison of the perspectives on building and facilities

\begin{tabular}{|c|l|l|}
\hline \multirow{2}{*}{ Attribute } & Examples of Evidence and Comparisons \\
\cline { 2 - 3 } & $\begin{array}{l}\text { Culinary Art } \\
\text { The current facilities and buildings are } \\
\text { almost appropriate for their designed } \\
\text { purposes of students training and the } \\
\text { practical sessions, however, when } \\
\text { graduates go out to the real hotel } \\
\text { environment, they feel some } \\
\text { differences in terms of equipment and } \\
\text { operation (CA2). }\end{array}$ & $\begin{array}{l}\text { Unfortunately, not all institutes have } \\
\text { the required training equipment, } \\
\text { facilities and restaurants for the } \\
\text { practical sessions, to meet which are } \\
\text { similar to those found in the hotels } \\
\text { and resorts (FS1). }\end{array}$ \\
\cline { 2 - 3 } & $\begin{array}{l}\text { For Somewhat the current facilities and } \\
\text { buildings especial the educational } \\
\text { kitchen are enough for their purpose } \\
\text { (CA3). }\end{array}$ & $\begin{array}{l}\text { In the current situation, there is some } \\
\text { of the institutes have educational } \\
\text { restaurants and therefore all other } \\
\text { institutes must without restaurants } \\
\text { should take them as a model to } \\
\text { follow (FS3). }\end{array}$ \\
\cline { 2 - 3 } & $\begin{array}{l}\text { Educational kitchens equipment and } \\
\text { institute buildings conform the } \\
\text { specifications of the higher education } \\
\text { ministry and operate efficiently } \\
\text { (CA13). }\end{array}$ & $\begin{array}{l}\text { For buildings, facilities and } \\
\text { equipment, are not enough to meet } \\
\text { the requirements in the educational } \\
\text { process. Thus students should visit } \\
\text { and get training chance in high } \\
\text { standard hotels and restaurants, in } \\
\text { order to learn how to deal with all } \\
\text { types of tools and equipment in } \\
\text { modern hotels and restaurants and to } \\
\text { avoid gaps (FS6). }\end{array}$ \\
\cline { 2 - 3 } & $\begin{array}{l}\text { I think they need to be updated to } \\
\text { commensurate with the scientific level }\end{array}$ \\
& $\begin{array}{l}\text { All fixtures and equipment located in } \\
\text { institutes of tourism and hotels, are }\end{array}$ \\
\hline
\end{tabular}




\begin{tabular}{|l|l|l|}
\hline $\begin{array}{l}\text { of the Higher Institutes for Tourism and } \\
\text { Hotels (CA15). }\end{array}$ & $\begin{array}{l}\text { below the required level and } \\
\text { inappropriate for their purpose, and } \\
\text { they (FS15). }\end{array}$ \\
\cline { 2 - 3 } $\begin{array}{l}\text { The different departments of the } \\
\text { educational kitchen should be all } \\
\text { according to the latest high-model. This } \\
\text { will help the students get used to the } \\
\text { form of the international cuisine. As } \\
\text { well as the students must be visiting the } \\
\text { international hotels (CA22). }\end{array}$ & $\begin{array}{l}\text { I think it is inadequate compared } \\
\text { other institutes. Thus, it should be } \\
\text { updated also to meet the innovation } \\
\text { in the hospitality industry (FS20). }\end{array}$ \\
\hline
\end{tabular}

\section{The perspective on teaching methods}

The related methods of teaching of both theoretical and practical session are among the main elements of the educational process which influence the quality and the gained skills of tourism and hospitality students. With this regard, the interviews results revealed that all respondents ( $\mathrm{n}=44 ; 22$ Culinary art and 22 food service) have reported on the significance of teaching methods, including the teaching hours, using information technology and hightech, and others. Table 6 summarizes and compares some of the respondents' points of view on the related methods of both culinary art and foodservice courses.

Table 6: the perspectives and the comparison on teaching methods

\begin{tabular}{|c|c|c|}
\hline \multirow{2}{*}{ Attribute } & \multicolumn{2}{|c|}{ Examples of Evidence and Comparisons } \\
\hline & Culinary Art & Food service \\
\hline \multirow{3}{*}{ 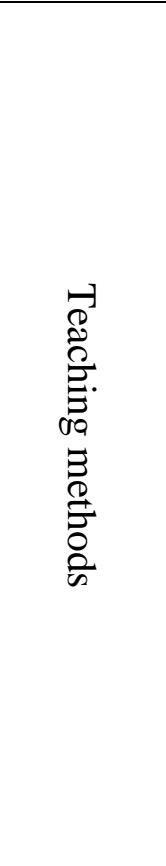 } & $\begin{array}{l}\text { The teaching methods should be } \\
\text { innovated and developed in order to } \\
\text { keep pace with all that is new in the } \\
\text { field of hotels and restaurants (CA1). }\end{array}$ & $\begin{array}{l}\text { The number of students should not be } \\
\text { more than } 15 \text { students in applied } \\
\text { sessions so that all of them can } \\
\text { practice the required tasks (FS1). }\end{array}$ \\
\hline & $\begin{array}{l}\text { The limited capabilities of some of } \\
\text { the institutes hamper to some extent } \\
\text { the full understanding of the student } \\
\text { of culinary art course, in particular } \\
\text { the practical side (CA3). }\end{array}$ & $\begin{array}{l}\text { The institutes should cooperate with } \\
\text { international hotels and restaurants } \\
\text { and other institute with regard to the } \\
\text { development of the teaching methods } \\
\text { of food beverage services, so as to } \\
\text { follow through effective teaching, } \\
\text { according to the technology era, as } \\
\text { well as favorable labor market, to } \\
\text { increase the competences of the } \\
\text { students (FS5) }\end{array}$ \\
\hline & $\begin{array}{l}\text { Evaluate teaching methods of the } \\
\text { culinary art course as they are in line } \\
\text { with reality by } 80 \% \text { (CA4). }\end{array}$ & $\begin{array}{l}\text { The existence of specialized training } \\
\text { courses in line with all the five-star } \\
\text { hotels is an important need for } \\
\text { effective teaching (FS9). }\end{array}$ \\
\hline
\end{tabular}

\section{The perspective on training related to $F \& B$ courses}

The related training and practical session are among the main factors influence the quality and the gained skills of tourism and hospitality students. With this regard, the interviews results revealed that all respondents ( $\mathrm{n}=44 ; 22$ Culinary arts and 22 food service) have reported on the significance of training aspects, including the training duration, time of training, level of training, place of training, the influence of training on the gaining new skills and competences. Table 7 summarizes and compare some of the respondents on the related training of both culinary art and foodservice courses. 
International Journal of Heritage, Tourism and Hospitality Vol. (11), No. (2/2), September, 2017

By: Faculty of Tourism and Hotels, Fayoum University

Table 7: the comparison of the perspectives on training related to FB courses

\begin{tabular}{|l|l|l|}
\hline \multirow{2}{*}{ Attribute } & \multicolumn{2}{|l|}{ Examples of Evidence and Comparisons } \\
\cline { 2 - 3 } & Culinary Art & Food service \\
\hline & $\begin{array}{l}\text { Training period must be longer } \\
\text { than one month (CA1) }\end{array}$ & $\begin{array}{l}\text { Training for the duration of } \\
\text { foodservice and beverages are } \\
\text { often inadequate and must focus } \\
\text { on the effective evaluation of } \\
\text { trainees, training and raising the } \\
\text { efficiency of the training via } \\
\text { follow-up training in hotels and } \\
\text { restaurants (FS2). }\end{array}$ \\
& $\begin{array}{l}\text { Training must be at least 3 } \\
\text { months, and every hotel has the } \\
\text { right to choose the appropriate } \\
\text { number of trainees to be trained } \\
\text { under his policy and system }\end{array}$ & $\begin{array}{l}\text { Summer training period or the } \\
\text { training duration during the term } \\
\text { is very short and not sufficient to } \\
\text { train students on all practical } \\
\text { aspects of foodservice to } \\
\text { improve their skills (FS4). }\end{array}$ \\
\cline { 2 - 3 } & $\begin{array}{l}\text { In terms of duration of training it } \\
\text { is inadequate and should be } \\
\text { increased to six months. The } \\
\text { number of trainees should be in } \\
\text { line with no of available space } \\
\text { for training in the hotels or the } \\
\text { restaurants. Additionally, the } \\
\text { evaluation of training must be } \\
\text { measured by the developed } \\
\text { students' skills. Finally, training } \\
\text { can be developed by let students } \\
\text { to be trained in all sections of } \\
\text { the hotels (CA6. }\end{array}$ & $\begin{array}{l}\text { Training module should be } \\
\text { added to the total marks of the } \\
\text { students in which the theoretical } \\
\text { and practical are evaluated. } \\
\text { Therefore, training can help in } \\
\text { the development and refinement } \\
\text { of the students' skills in } \\
\text { preparation for the job market } \\
\text { (FS5). }\end{array}$ \\
& & \\
& &
\end{tabular}

\section{The perspective on evaluation of $F \& B$ courses}

Interviewees expressed their points of views on the current methods and techniques used for evaluating $F \& B$ related courses. The results exposed that most of interviewees expressed their perceptions, which were different from respondent to another as it can be noted from Table 9.

Table 8 the perspectives on evaluation of $F \& B$ courses

\begin{tabular}{|c|c|c|}
\hline \multirow{2}{*}{ Attribute } & \multicolumn{2}{|l|}{ Examples of Evidence and Comparisons } \\
\hline & Culinary Art & Food service \\
\hline 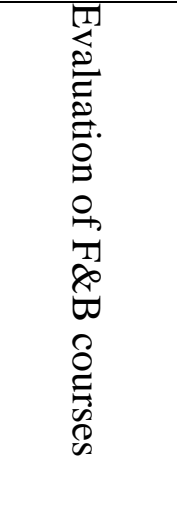 & $\begin{array}{l}\text { I do not know anything about the } \\
\text { theoretical evaluation, but with } \\
\text { respect to the practical assessment, I } \\
\text { can say that the level of evaluation } \\
\text { is beyond the levels that achieve the } \\
\text { quality of graduates, as most of the } \\
\text { students during the training do not } \\
\text { practice the tasks themselves or by } \\
\text { their hand, therefore any skills does } \\
\text { not appear upon the process and } \\
\text { professionalism of the profession }\end{array}$ & $\begin{array}{l}\text { The assessment of the student with } \\
\text { regard to the foodservice course should } \\
\text { be comprehensive assessment of the } \\
\text { cumulative in the sense that the } \\
\text { evaluation should be not only in the } \\
\text { theoretical test applied but must be } \\
\text { phased evaluation of each task or studied } \\
\text { the student teach giving evaluation, } \\
\text { unfortunately, this is not available in } \\
\text { private institutions (FS1) }\end{array}$ \\
\hline
\end{tabular}




\begin{tabular}{|l|l|l|}
\hline $\begin{array}{l}\text { fact that students have is a creative } \\
\text { and non-creative (CA 2). }\end{array}$ & $\begin{array}{l}\text { I can see that the current techniques } \\
\text { of food culinary art course are } \\
\text { excellent with respect to the } \\
\text { theoretical and practical aspect, } \\
\text { however, more focus on the } \\
\text { practical side of the evaluation } \\
\text { should be taken into account (CA5). }\end{array}$ & $\begin{array}{l}\text { The current academic evaluation of F\&B } \\
\text { is quite different from the practical life } \\
\text { (FS3) }\end{array}$ \\
$\begin{array}{l}\text { It is necessary to develop the } \\
\text { culinary art course from both } \\
\text { practice and theory; it must be } \\
\text { developed in accordance with } \\
\text { international and global hotels. As } \\
\text { well as the evaluation must be } \\
\text { linked between the theoretical and } \\
\text { practical approaches (CA19) }\end{array}$ & $\begin{array}{l}\text { The assessment should be cumulative in } \\
\text { the sense that the stages during the } \\
\text { academic year (FS11). }\end{array}$ \\
$\begin{array}{l}\text { Professionals and other } \\
\text { stakeholders should be involved in } \\
\text { the evaluation processes of } \\
\text { behavioral skills (CA12). }\end{array}$ & $\begin{array}{l}\text { The evaluation process of food and } \\
\text { beverage related courses should be } \\
\text { developed with the new aspects in the } \\
\text { hospitality industry (FS21). }\end{array}$ \\
\hline
\end{tabular}

\section{Conclusions, implications and limitations}

This study is the first in the Egyptian context to address the evaluation of F\&B related courses in the private high tourism and hotels institutes. Using a qualitative approach and employing an in-depth structured interview technique. This study suggests that most of professionals believed that most of students enrolled in hotels and tourism institutes are not ready or do not have the ability to work in food and beverage department, in particular in food service rather than the kitchen. Additionally, there is a variation among the teaching staff with regard to their level of professionalism and academic qualifications. While some of them have the required skills and professionalism which are enough and meet the requirements, other believed that there is more need for teaching staff to be trained and developed. As well as the study findings suggested that there are variations in the current contents of $F \& B$ related courses. As while some believe they meet the requirements and enough to build skill and competences required by the market, others though the opposite.

Another interesting finding of this study is that the methods of teaching of both theoretical and practical session are among the main elements of the educational process which influence the quality and the gained skills of tourism and hospitality students and graduates. The findings of this study have reported on the significance of teaching methods, including the teaching hours, using information technology and high-tech, and others. Also, an extensive attention is required for using new teaching methods in both theoretical and practical aspects of F\&B courses. Furthermore, most of respondents underlined the significance of training aspects, including the training duration, time of training, level of training, place of training, the influence of training on the gaining new skills and competences. However, more attention is required concern the length of training, in particular, practical training, e.g. 3 months.

Similar to other studies, this study has some limitations, including the number of participated institutes, where only four high private tourism and hotels institutes were studies due to the ability and accessibility for data, time limitation and also cost and the 
researcher ability. Another limitation is that the number of academic and professional teaching staff was also purposively chosen with the four institute's context. These limitations can help future research on this area.

Finally, it is important to conclude that the findings of this study may be useful for academic and professionals in improving and developing F\&B related courses. In the end of the interview schedule, the interviewees were courteously asked to add any further suggestions and recommendations, which may help to improve and develops the current situation of the evaluation of F\&B related courses, in particular the culinary art and foodservice courses. Most of respondents have suggested some issues and recommendations, the most influential and reputed ones including,

'Teaching foodservice course in English' (FS15); 'Increase the required summer training' (FS19); 'Curriculum should be developed and improved to be in line with the market requirement' (FS19); 'Continuous training' (FS21); 'Provide specialized booklets in F\&B for students' (FS22).

\section{References}

Abdel Hamid, G., Saad, R., Gomma, H., Khalifa, A., \& Gadallah, Y. (2010). Higher Education in Egypt: Country Review Report: Strategic Planning Unit, Ministry of Higher Education, Egypt.

Afifi, G. (2011). E-learning as an alternative strategy for tourism higher education in Egypt. Quality Assurance in Education, 19(4), 357- 374.

Baker, M., Cattet, A., \& Riley, M. (1995). Practical food and beverage training in the UK: Astudy of facilities and a debate on its relevance. International Journal of ContemporaryHospitality Management, 7(5), 21-24.

Botterill, D. (2002). Tourism studies and research quality assessment in UK universities. Journal of Hospitality, Leisure, Sport and Tourism Education, 1(2), $71-74$.

Breiter, D., \& Dements, C. J. (1996). Hospitality management curricula for the 21st century. Hospitality \& Tourism Educator, 8(1), 57-60.

Chung, K. Y. (2000). Hotel management curriculum reform based on required competencies of hotel employees and career success in the hotel industry. Tourism management, 21(5), 473-487.

Cousins, J., Foskett, D., \& Gillespie, C. (2002). Food and beverage management. Pearson Education.

Fields, K. (2002). Demand for the gastronomy tourism product: motivational factors. Tourism and gastronomy, 36-50.

Ford, R. \&LeBrunto, S. (1995). Management education in the USA - How much practical hotel management education is necessary? International Journal of Contemporary Hospitality Management, 7(5), 1-4.

Gillespie, C., \& Baum, T. (2000). Innovation and creativity in professional higher education: The development of a CD-ROM to support teaching and learning in food and beverage management. Scottish Journal of Adult and Continuing Education, 6(2), 147-165.

Goldsmith, A., \&Salehuddin MohdZahari, M. (1994). Hospitality education in Malaysia: Filling the skill gap. International Journal of Contemporary Hospitality Management, 6(6), 27-31.

Goodman Jr, R. J., \& Sprague, L. G. (1991). The future of hospitality education: Meeting the industry's needs. The Cornell Hotel and Restaurant Administration Ouarterly, 32(2), 66-70.

Hall, C. M., Williams, A. M., \& Lew, A. A. (2004). Tourism: Conceptualizations, institutions, and issues. A companion to tourism, 3-21.

Harrington, R. J., Mandabach, K. H., VanLeeuwen, D., \&Thibodeaus, W. (2005).A multilens framework explaining structural differences across foodservice and 
culinary education.International Journal of Hospitality Management, 24(3), 195218.

Hewedi, M., Doma, N., \& AL-Hamamsy, S. (1998). Hospitality Education in Egypt: an Overview. Paper presented at the 2nd International Conference on Culinary Arts and Sciences, University of Bournemouth, UK.

Hill, F. M. (1995). Managing service quality in higher education: the role of the student as primary consumer. Ouality assurance in education, 3(3), 10-21.

Hjalager, A. M. (2003). Global tourism careers? Opportunities and dilemmas facing higher education in tourism. Journal of Hospitality, Leisure, Sport and Tourism Education, 2(2), 26-37.

Horng, J. S; .Hu, M. L. M., , \& Sun, Y. H. C. (2009). Hospitality teams: Knowledge sharing and service innovation performance. Tourism Management, 30(1), 41-50.

Jafari, J., Pizam, A., \&Przeclawski, K. (1990).A sociocultural study of tourism as a factor of change. Annals of Tourism Research, 17(3), 469-472.

Jones, P. (2004). Finding the hospitality industry? Or finding hospitality schools of thought. Journal of Hospitality, Leisure, Sport and Tourism Education, 3(1), 33-45.

Kattara, H. S., Eraqi, M., \&Hewedi, M. (2004). Tourism and hospitality postgraduate research experience: A highlight of tourism and hospitality research issues in Egyptian higher education. Journal of teaching in travel \& tourism, 4(2), 1-17.

Lin, S. C. (2002). Exploring the relationships between hotel management courses and industry required competencies. Journal of teaching in travel \& tourism, 2(3-4), 81101.

Millar, M., Mao, Z., \&Moreo, P. (2010). Hospitality \& tourism educators vs. the industry: A competency assessment. Journal of Hospitality \& Tourism Education, 22(2), 3850.

O’Mahony, G.B., McWilliams, A.M., \& Whitelaw, P.A. (2001). Why students choose a hospitality degree program. The Cornell Hotel and Restaurant Administration Ouarterly,42(1), 92-96.

Phelan, K. V., Meiia, C., \& Hertzman, J. (2013). The industry experience gap: Hospitality faculty perceptions of the importance of faculty industry experience. Journal of Hospitality \& Tourism Education, 25(3), 123-130.

Roney, S. A., \&Oztin, P. (2007). Career perceptions of undergraduate tourism students: A case study in Turkey. Journal of Hospitality, Leisure, Sport and Tourism Education, 6(1), 4-17.

Scheule, B., \& Sneed, J. (2001). Teaching leadership in hospitality management programs: A model for learning from leaders. Journal of Hospitality \& Tourism Education, 13(2), 35-38.

Stutts, A. T. (1995). Viewpoint: Higher education in hospitality management. International Journal of Contemporary Hospitality Management,7(6), 52\}53.

Unklesbay, N., Sneed, J., \&Toma, R. (1998). College students' attitudes, practices, and knowledge of food safety. Journal of Food Protection, 61, 1175-1180.

Walczak, D. (1997). The sanitation imperative: Keep people from getting sick in your restaurant. The Cornell Hotel and Restaurant Administration Quarterly, 38(2), 6873.

Wood, R. E. (1997). Tourism and the state: Ethnic options and constructions of otherness. Tourism, ethnicity, and the state in Asian and Pacific societies, 1-34.

Wu, B., Morrison, A. M., Yang, J. K., Zhou, J. L., \& Cong, L. L. (2014). Cracks in the ivory tower? A survey-based analysis of undergraduate tourism education and educators in China. Journal of Hospitality, Leisure, Sport \& Tourism Education, 14, 26-38. 